\title{
THE PLATONIC MILIEU OF DIONYSIUS THE PSEUDO-AREOPAGITE
}

\section{THEODORE SABO}

DAN LIOY

RIKUS FICK

NORTH-WEST UNIVERSITY, POTCHEFSTROOM

\begin{abstract}
The Platonic milieu is the most significant of the possible milieus that can be attributed to the Proto-Hesychast Dionysius the Pseudo-A reopagite. The present article hypothesizes that Dionysius' master Hierotheus was I sidore of A lexandria, a disciple of the Neoplatonist Proclus, and posits that Dionysius' locale was Egyptian rather than Syrian. Certain aspects of Proclus' influence on him are also taken into account, namely his discussion of evil, his imagery of the statues, his system of henads, and his subscription to theurgy. Dionysius' understanding of theurgy was, however, opposed to that of Proclus' ultimate mentor Porphyry for whom theurgy and virtue were mutually exclusive paths. $\mathrm{H}$ is description of the vision of Carpos tends to underscore this.
\end{abstract}

Keywords: Damascius, Dionysius the Pseudo-A reopagite, Eastern Orthodox Church, Hesychasm, Isidore of Alexandria, late antiquity, Neoplatonism, Patristics, Platonism, Proclus, theurgy.

\section{INTRODUCTION}

Of the possible milieus of the Christian philosopher Dionysius the Pseudo-A reopagite the Platonic is perhaps the only certain one. Dionysius, who posed as St. Paul's convert Dionysius of $A$ thens, was young enough to have studied Proclus and old enough to have been quoted with approval by the Monophysite representatives to the colloquy before the emperor Justinian in 532; the representatives found the quotations in Severus of 
A ntioch's writings. ${ }^{1}$ It is difficult to date the writings of both Severus and Damascius, who resemble Dionysius, and this fact plays into the shifty author's hands.

Dionysius' influence on Western Christian mysticism has been exaggerated. Aquinas accepted him, balancing his mysticism with his own scholasticism, but no one fully embraced Dionysius in the West until M eister Eckhart who transformed rather than extensively used his thought and who was at least equally dependent on such female mystics as Hadewijch, M echthild of $\mathrm{M}$ agdeburg, and $\mathrm{M}$ arguerite Porete. ${ }^{2}$ Rorem finds Dionysius more influential in the Western church than the Eastern church. ${ }^{3}$ The present writer disagrees and sides on this matter with Leclercq who sees a dearth of Dionysian influence in Western Christianity. ${ }^{4}$ Rorem himself acknowledges Dionysius' impact on various aspects of Eastern Orthodox mysticism such as the J esus prayer, monasticism, and theōsis.

\section{DIONYSIUS AND HIEROTHEUS/ISIDORE}

Dionysius claims to have been the student of Hierotheus, a supposed disciple of Paul to whom he attributes an Elements of Theology, the selfsame title of a work by the $\mathrm{N}$ eoplatonist Proclus. $\mathrm{H}$ is descriptions of $\mathrm{H}$ ierotheus have correspondences with those of Proclus as depicted in M arinus' biography. ${ }^{5} \mathrm{He}$ places Hierotheus among the disciples gathered around the dying $M$ ary and a partaker with them of a vision accompanying her death. A fter the vision all who witnessed it spoke some words of appreciation, but none was as mystical as Hierotheus. 'He was so caught up', Dionysius writes, 'so taken out of himself, experiencing communion with the things praised, that everyone who heard him, everyone who saw him, everyone who knew him (or, rather, did not know him) considered him to be inspired, to be speaking with divine praises. ${ }^{\prime}{ }^{6}$

Dionysius credits Hierotheus with having written hymns, namely the E rotic $\mathrm{H}$ ymns or Hymns of Yearning; ${ }^{7}$ it is likewise known that Proclus wrote a hymn in honour of the Semitic deity Theandrites. But when he announces that Hierotheus' faith was

1 Claudio M oreschini and Enrico N orelli, Early Christian Greek and Latin Literature: A Literary H istory (trans. M. J. O’Connell; 2 vols; Peabody: Hendrickson, 2005), 2:665-666.

2 Ps.-Dionysius, The Complete Works (trans. C. Luibheid and P. Rorem; N ew York: Paulist Press, 1987), 30, 224.

3 Ps.-Dionysius, The Complete Works, 227.

4 Ps.-Dionysius, The Complete Works, 25-32; cf. L outh, D enys the Areopagite, 125-126.

5 M oreschini and Norelli, Early Christian Greek and Latin Literature, 2:669.

6 Ps.-Dionysius, Divine Names 681c-684a; The Complete Works, 70.

7 Ps.-Dionysius, Divine Names, 713a; The Complete Works, 83. 
independent of any education, one is reminded more of a student of Proclus who will shortly be considered. ${ }^{8}$

Gersh is convinced that Dionysius studied under Proclus in A thens. ${ }^{9}$ This is going too far, but, if true, it would recall the careers of the Proto-Hesychasts Basil the Great and Gregory of Nazianzus. ${ }^{10}$ The hypothesis does not defy credulity if it is remembered that Proclus had Christian students, in part due to the increasing reliance of Christians on pagan philosophy and logic as an aid for navigating their way through the Christological crises of the fifth century.

Dionysius' arrogance does not obscure a pal pable reverence for Hierotheus which leads one to conclude that Hierotheus was no figment of his imagination. His respect for his teacher is a reflection of Greek thought in which the master's personality was indispensable to the pupil's advancement in learning. ${ }^{11}$ If Hierotheus was not Proclus himself he was an emulator of Proclus, a minor yet charismatic teacher who inadvertently left a considerable mark on subsequent Proto-Hesychasm. The teachings Hierotheus passed on to Dionysius are Neoplatonic: procession and return, the concept of God as beyond being, and the division of the angels into three groups of three ranks. ${ }^{12}$

There are unmistakable parallels between Hierotheus and Isidore of A lexandria, notably their debt to Proclus, their evident charisma, and their restriction of their intake of reading..$^{13}$ If Hierotheus and Isidore are the same person a perusal of Damascius' Philosophical History, requested by Theodora of Emesa to commemorate the life of Isidore, would not be an unwise venture for the scholar of Proto-Hesychasm. A Ithough this is a tenuous proposal it is less preposterous than the view of R osemary A rthur that Hierotheus was a practitioner of Jewish Hekhaloth mysticism. ${ }^{14}$ The two individuals (Hierotheus and Isidore) at least breathed the same philosophical air.

Dionysius' respect for Hierotheus is suspiciously similar to Damascius' attitude toward Isidore; both of the 'pupils' flourished around 500. It is unlikely that the

8 Ps.-Dionysius, Divine Names 648b; Damascius, Hist. Phil. 35; The Complete Works, 65; The Philosophical H istory (trans. P. A thanassiadi; A thens: A pamea Cultural A ssociation, 1999), 115. Y et a lack of education was also prized in Christian circles. See Vit. Ant. 72; A thanasius, The Life of Antony and the Letter to M arcellinus (trans. R. C. Gregg; M ahwah: Paulist Press, 1980), 83.

9 Stephen Gersh, F rom Iamblichus to Eriugena (Leiden: B rill, 1978), 1.

10 J onathan Hill, The H istory of Christian Thought (Downers Grove: InterVarsity, 2003), 69.

11 Rosemary A. Arthur, Pseudo-Dionysius as Polemicist: The Development and Purpose of the Angelic Hierarchy in Sixth Century Syria (Aldershot: A shgate, 2008), 3; John Dillon, The M iddle Platonists: 80 BC-AD 220 (Ithaca: Cornell University Press, 1996), xv.

12 A rthur, P seudo-Dionysius as Polemicist, 30.

13 Ps.-Dionysius, Divine Names 648b; The Complete Works, 65; Damascius, Hist. Phil. 35; The Philosophical History, 115.

14 A rthur, P seudo-Dionysius as Polemicist, 28, 189. 
Areopagite is to be equated with Damascius in view of the latter's fervent antiChristianity which is spread liberally, albeit in a careful way, throughout the pages of the P hilosophical History. Yet parallels between individuals can point to a common master. ${ }^{15}$ Parallels between Damascius and Dionysius are their stylistic brilliance, their love of storytelling, ${ }^{16}$ their subscription to the concept of an ineffable principle beyond God, their situating of this principle in thick darkness, their comparison of the search for God to the ascent up a mountain (though Dionysius probably found this in G regory of Nyssa), ${ }_{1}^{17}$ and their toning down of the evil nature of matter. ${ }^{18}$ Syrianus was ultimately responsible for the last position, but Plotinus had given impetus to it in his treatise against the Gnostics, reacting to them and even to an insightful statement of the Neopythagorean N umenius. ${ }^{19}$

Whether or not the Areopagite studied under Proclus or Isidore in the flesh it is clear that he cut his teeth on the former's treatises and commentaries; this is especially evident in The Divine Names. He tells Timothy that he accepts Hierotheus' writings second only to Scripture, ${ }^{20}$ and this is something he can be accused of doing in the case of Proclus. He terms the scriptural writers theologians, the closest word he can get to philosopher without being unbiblical. Often he seems more interested in Proclus than in Scripture which he does not tend to quote at length. An exception is Romans 1:20 which he quotes while rebutting sun worship, previously indulged in by Julian the Apostate. ${ }^{21}$ $\mathrm{His}$ biblical interpretations were also more radical than was usual in his day. ${ }^{22}$

Sheldon-Williams thinks Hierotheus was a real person but one not to be identified with Proclus..$^{23}$ This is reasonable, but not his subsequent statement that since little is known of Proclus' predecessors Dionysius may have been influenced by them rather than by Proclus. He bases his claim on the fact that Dionysius' Christian sources are from the fourth century but not the fifth century which is when Proclus lived. Against this theory it may be posited that Dionysius was little interested in the theology, as opposed to the philosophy, of his time, but that he was not completely ignorant of it is proven by his

15 Dillon, The Middle P latonists, 382.

16 Damascius, Hist. Phil. 138, 142; The Philosophical History, 309-311, 315; cf. 60; Ps.-Dionysius, Divine Names 681c-684a; Ep. 1097b, 1100d; The Complete Works, 70, 278-280.

17 Gregory of Nyssa, Vit. Moys. 2.152-161; The Life of Moses (trans. A. J. Malherbe and E. Ferguson; N ew York: Paulist Press, 1978), 91-94.

18 A rthur, P seudo-Dionysius as Polemicist, 31.

19 Plotinus, Enn. 2.9; Calcidius, Comm. Tim. 113ff.; Dillon, 374.

20 Ps.-Dionysius, Divine Names 681b; The Complete Works, 69-70.

21 Ps.-Dionysius, Divine Names 700c; The Complete Works, 75.

22 See especially his favorable attitude toward the builders of the Tower of Babel in Ep. 1105b; The Complete Works, 282.

23 I. P. Sheldon-Williams, "The Pseudo-Dionysius," in The Cambridge H istory of Later Greek and Early M edieval Philosophy (ed. A. H. Armstrong; Cambridge University Press, 1967), 457-458. 


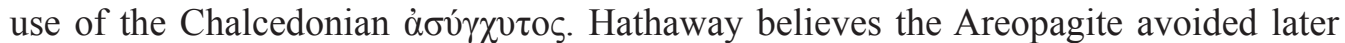
theologians as an act of deliberate subterfuge. ${ }^{24} \mathrm{G}$ rondijs has in fact shown Dionysius' dependence on post-Procline thinkers, notably in his use of the words $i \pi \varepsilon \rho \alpha \gamma v \omega \sigma i ́ \alpha$ and $\tau \mu \iota \dot{\omega} \tau \eta{ }^{25}$ One can still therefore place him at the end of the fifth century or the beginning of the sixth.

\section{AN EGYPTIAN DIONYSIUS?}

Dionysius was not necessarily a Syrian as has been alleged, on the basis of his description of the sacrament of myron, but perhaps an Egyptian or at least a Greek Egyptian. Rutledge takes him for either an Egyptian or a Syrian. ${ }^{26} \mathrm{His}$ familiarity with Neoplatonism and tendency towards Monophysitism fit what is known about the philosophical school of A lexandria as it existed under the leadership of the N eoplatonist H orapollo. ${ }^{27} \mathrm{H}$ orapollo's M onophysite students included Severus of A ntioch, Zacharias of M itylene, and A thanasius II, and Pseudo-Dionysius would have been at home in the company of such spirits. One of his first translators, Sergius of Reshaina, studied in A lexandria. There are parallels, as has been seen, between his thought and that of Damascius who spent much time in Alexandria. Didymus the Blind also noted the reverence the A lexandrians had for angels which is certainly exhibited by Dionysius. ${ }^{28}$ Nor would his A lexandrian origins rule out the possibility of him studying in A thens, the home of Proclus and the sometime haunt of Isidore. ${ }^{29}$ Significantly he claims to have been in Heliopolis, southeast of Alexandria, at the time of the crucifixion. It is not irrelevant that his description of the supernatural eclipse at that time derives from an A lexandrian variant of Luke 23:44-45. ${ }^{30}$

Nonetheless Dionysius' Syrian origin cannot be dismissed out of hand. Rorem posits that his unawareness of the singular form of the Hebrew śerapîm militates against his knowledge of Syriac, but Syriac renders plurals differently than Hebrew and in any case the possibility that Dionysius was a solely Greek-speaking Syrian cannot be ruled out. He elsewhere refers, clearly in the third person, to those who know Hebrew which would imply that he knew no Hebrew ${ }^{32}$ himself and possibly no Syriac either.Y et

24 Riordan, Divine Light, 27-28.

25 A rthur, P seudo-Dionysius as Polemicist, 30-31.

26 Riordan, Divine Light, 28.

27 Damascius, Hist. Phil. 120; The Philosophical H istory, 283-285.

28 A rthur, Pseudo-Dionysius as Polemicist, 96.

29 Damascius, Hist. P hil. 59, 145; The P hilosophical H istory, 165, 319.

30 Ps.-Dionysius, The Complete Works, 268.

31 Rorem, Pseudo-Dionysius, 70.

32 Ps.-Dionysius, Cel. Hier. 205b; Eccl. Hier. 481c, 485ab; The Complete Works, 161, 230, 232. 
perhaps he was a Semitic speaker after all and this was another subterfuge. He is aware of the relationship between śr rappim (seraphim) and śärap (to burn), and he refers to the deacons as cleansers which may indicate a rudimentary acquaintance with Syriac. ${ }^{33}$

\section{THE PROCLINE INFLUENCE}

Dionysius was eager to capitalize on the affinities between Origen and the Cappadocians on the one hand and the Neoplatonists on the other, ${ }^{34}$ and he hence passed on, with Maximus the Confessor, a strong dose of philosophy to the Hesychasts. He did not hesitate to appropriate Proclus' ideas and writings, notably his treatise on evil in The Divine Names in which he changed only two things in the interest of Christian theology: he made the daemons fall and denied that evil could be attributed to animals or to matter. ${ }^{35} \mathrm{He}$ strongly echoes Proclus in denying the independent existence of evil which is the partial absence of good, partial because if it was totally absent of good it would not even have existence. In addition to Proclus' influence one can detect an indebtedness to Syrianus and Plato's Parmenides. This formidable dialogue was undergoing a renaissance thanks to the N eoplatonists. Proclus and his disciple $\mathrm{M}$ arinus each wrote a commentary on it, and Damascius, as was his custom, wrote a commentary on Proclus' commentary. ${ }^{36}$

Dionysius' dependence on Proclus cannot be overstressed. He claims that great and small, identical and different, similar and dissimilar, and rest and movement can be attributed to God, the identical claim of Syrianus and Proclus in their interpretation of the $\mathrm{P}$ armenides.$^{37}$ Dionysius is the only ancient writer to have used the word $\theta \varepsilon \alpha v \delta \rho ı$ có a word that becomes more illuminating when Proclus' hymn in honour of Theandrites is remembered. When he spoke of 'the statues that are the divine names' he had in mind the old Greek custom of carving hollow statues, without feet or hands, of Hermes and Silenus. Each statue had a door which the devotee opened to place smaller statues of the gods he most reverenced inside. The names of God were like the statues of Hermes, disclosing nothing to the uninitiated and concealing all their beauties within. ${ }^{38}$

33 A rthur, P seudo-Dionysius as Polemicist, 13, 66.

34 Sheldon-Williams, "The Pseudo-Dionysius," 457-458.

35 Proclus, On the Existence of Evils (trans. J. Opsomer and C. Steel; Ithaca: Cornell U niversity Press, 2003), 4-5.

36 Damascius, Hist. P hil. 97; The P hilosophical H istory, 239, 45-46.

37 Dominic J. O'M eara, ed., Neoplatonism and Christian Thought (Norfolk: International Society for Neoplatonic Studies, 1982), 67.

38 0'M eara, Neoplatonism and Christian Thought, 70-71. 
For Proclus as well, and for his mentor Plutarch of A thens, the divine names had replaced the statues which were being destroyed by the Byzantine emperors. Proclus witnessed the removal of the statue of A thena from the Athenian acropolis and subsequently dreamed that the goddess appeared to him with the words, 'Lady Athenais intends to stay with you.' ${ }^{39}$ Dionysius was indebted to the Neoplatonists not only for his imagery of the statues but for his use of the word 'henad' to describe the angelic hierarchy beneath God; while Proclus had termed the One the 'Henad of the henads' Dionysius called God 'the unifying Henad of all henads'. ${ }^{40}$

In a recent study Riordan attempts to separate Dionysius from his Neoplatonist bearings. ${ }^{41}$ This he does by averring that he had a higher view of matter than the Neoplatonists, that his metaphysical hierarchies issue forth because of love (हp $\omega \varsigma$ ) rather than necessity ( $\dot{\alpha} v \alpha \gamma \kappa \eta)$ ), and that God is not only one but three or, as he

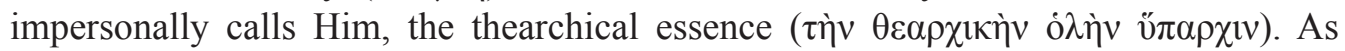
for the first point, Dionysius certainly does not devaluate the material world as much as earlier N eoplatonists like Plotinus and Porphyry. He even asserts that matter is not complete chaos because it is connected with order and has the power of generation; but his position is not so much because of his theological orthodoxy as because of the fact that in later $\mathrm{N}$ eoplatonism there is less hatred for matter than in earlier N eoplatonism, so even this un-Platonic situation is Neoplatonic in origin. In his use of है $\rho \omega \varsigma$ Dionysius was imitating Proclus ${ }^{42}$ and, as with Proclus, the term tended to be somewhat metaphorical and obfuscating, meaning only that God is 'constitutively present' to his creatures, 'providing them with all that they are as the differentiated manifestation of himself' in Perl's words. ${ }^{43}$ R egarding the last point, while N eoplatonism did not accept the Trinity it certainly had three initial hypostases which seem to have inspired Dionysius' thinking on the subject of the ultimate more than the Trinity itself did.

Riordan also fails to stress the influence Neoplatonic theurgy had on Dionysius. No Christian writer before or after him used the word $\theta \varepsilon o v p \gamma i \alpha$ to the extent that he did. Even a pagan work like Iamblichus' De Mysteriis employs it less than the Dionysian writings. Dionysius uses the word $\theta \varepsilon o v \rho \gamma i \alpha$ or one of its derivatives forty-eight times. ${ }^{44}$

39 O'M eara, Neoplatonism and Christian Thought, 70.

40 O'M eara, Neoplatonism and Christian Thought, 74.

41 Riordan, Divine Light, 89-90, 132.

42 John M. Rist, Eros and Psyche: Studies in Plato, Plotinus, and O rigen (U niversity of Toronto Press, 1964), 218-219.

43 Eric D. Perl, Theophany: The Neoplatonic Philosophy of Dionysius the Areopagite (State University of New York, 2007), 45.

44 V ladimir K harlamov, The B eauty of the U nity and the Harmony of the Whole: The Concept of Theosis in the Theology of Pseudo-Dionysius the Areopagite (E ugene: Wipf, 2009), 135. 
He even terms the Eucharistic rites the $\theta$ covpría $\mu v \sigma \tau \eta \rho$ ó, the mysteries by which one is made godlike. His use of the idea and terminology of theurgy can be linked with the Chaldean Oracles whose author is termed $\theta$ covprós, though his use of Oracular language probably derived from the school of Proclus. An instance of this language is his description of Jesus and the Holy Spirit as flowers and lights above being. ${ }^{45}$

A nyone who doubts the impact of theurgy on Dionysius' age need only consult Damascius' Philosophical History which is full of the occult and the magical. Two illustrations will suffice for now. Damascius says that he attended a paranormal session in which a young woman poured water into a glass cup and explained the prophetic images she saw there. It is likely that D amascius' colleague A sclepiodotus the Y ounger had recourse to such divination before he chose to leave A lexandria for A phrodisias and so escape Christian persecution. ${ }^{46}$ Damascius also relates that he was privileged to see a baetyl, a heavenly stone or meteorite, al ternately resting in the hands of its guardian E usebius, hiding in his clothes, or moving through the air. Eusebius had found the baetyl near a mountain at night, and the baetyl had informed him that it was the possession of the Heliopolitan god Gennaios. The stone was usually white but sometimes purple and was covered with vermilion letters which Eusebius could interpret as he could the whistling of the stone when it ran into walls. ${ }^{47}$ This can be compared to Dionysius' use of multicolored stones (white, red, yellow, and green) to describe the angels. ${ }^{48}$ In line with all this is the Orthodox scholar Florovsky's assertion that Dionysius' terminology recalls that of the Greek mysteries. ${ }^{49}$

Porphyry had said that theurgy and virtue were mutually exclusive paths, ${ }^{50}$ but there is a strong moral message in Dionysius. He was acquainted with a saint, a Cretan named Carpos, ${ }^{51}$ who instead of interceding for the restoration of two apostates prayed for their judgment. One night his bedroom seemed to be split in two from the roof down until he stood in an open space. J esus and the angels were above him, and below him was a chasm at the top of which the apostates struggled to free themselves from serpents who

45 O'M eara, Neoplatonism and Christian Thought, 71-72; cf. Chal. Or. Fr. 1; Dillon, The Middle Platonists, 393.

46 Damascius, Hist. Phil. 129, 95; The Philosophical H istory, 293, 233.

47 Damascius, Hist. Phil. 138; The Philosophical History, 309-311; cf. Yeats, The Celtic Twilight, 44.

48 Cel. Hier. 336c; Ps.-Dionysius, The Complete Works, 188 (with some interesting exegesis of Revelation 4:3; 21:19-21).

49 Georges Florovsky, The Byzantine Ascetic and Spiritual Fathers (trans. R. Miller, A.-M. Döllinger-Labriolle and H. W. Schmiedel; Vaduz: B üchervertriebsanstalt, 1987), 210.

50 Andrew Smith, Porphyry's Place in the Neoplatonic Tradition: A Study in Post-Plotinian Neoplatonism (The Hague: Nijhoff, 1974), 60-61.

51 Cf. 2 Timothy 4:13. 
were attempting to drag them down into the pit. Carpos, in his righteous indignation, tried to aid the serpents, but J esus descended from His throne and took the apostates to Himself, asking Carpos if it was not possible that he deserved to live with the serpents rather than with God and $\mathrm{His}$ angels. ${ }^{52}$

A Platonic reader might have noticed a similarity between this story and that of the judgment and rescue of $\mathrm{M}$ iltiades in the $\mathrm{G}$ orgias. ${ }^{{ }^{3}} \mathrm{~B}$ ut it is al so a foreshadowing of the Hesychastic exaltation of compassion. Dionysius' words about Carpos' later career are a prophecy of another Proto-H esychast, Symeon the N ew Theologian: 'He never began the holy sacraments of the mysteries without having a propitious vision first appear to him in the preliminary sacred prayers. ${ }^{.54}$

This brings up the importance of prayer in Proto-Hesychasm. The activity does not as a rule play a great part in the Proto-Hesychasm of Dionysius, but he opens his M ystical Theology with a prayer and speaks of the chain of prayer whereby the initiate is lifted upwards to God. ${ }^{55}$ The analogy is not unrelated to the concept of the chain of being, known by the Platonists and the A ristotelians, and to the golden chain, a metaphor for a kind of apostolic succession that was prominent in N eoplatonic circles and which would affect the monastic thought of Symeon the N ew Theologian ${ }^{56}$ as well as a pronouncement of the bishops of Chalcedon. ${ }^{57}$

\section{CONCLUSION}

The present article has focused on the Platonic and specifically Neoplatonic milieu of Dionysius the Pseudo-A reopagite and has additionally drawn attention to his possible Egyptian locale and the thesis that his revered Hierotheus was Isidore or at least a charismatic student of Proclus. Together with M aximus the Confessor, Dionysius was an important philosophical, as opposed to ascetical, influence on Hesychasm. His

52 Ep. 1097b-1100d; Ps.-Dionysius, The Complete Works, 278-280.

53 Plato, Gorg. 516; Plato, The Dialogues of Plato (trans. B. Jowett; Chicago: Encyclopaedia B ritannica, 2007), 289.

54 Ps.-Dionysius, Ep. 1097bc; The Complete Works, 278; Symeon the N ew Theologian, 153; Pract. and Theol. Texts 153 The Philokalia: The Complete Text Compiled by St. Nikodimos of the Holy M ountain and St. Makarios of Corinth (trans. G. E. H. Palmer, Ph. Sherrard and K. Ware; 4 vols; London: Faber, 1979-95), 4:62-63.

55 Ps.-Dionysius, Divine Names 680c; The Complete Works, 68.

56 Hilarion Alfeyev, St. Symeon the New Theologian and Orthodox Tradition (Oxford University Press, 2000), 141-142.

57 Leo, Ep. 98; The Acts of the Council of Chalcedon (trans. R. Price and M. Gaddis; 3 vols; Liverpool U niversity Press, 2005), 3:121; cf. Homer, II. 8.20-24; The Iliad (trans. R. Fitzgerald; New York: Farrar, 2004), 176; Algis Uždavinys, ed., The Golden Chain: An Anthology of Pythagorean and Platonic P hilosophy (Bloomington: World Wisdom, 2004), ix. 
system is unthinkable without the prior example of Proclus, just as Gregory of Nyssa is unthinkable without Plotinus and Origen without the M iddle Platonists; but because of the overwhelming influence of Proclus on his philosophy he does not deserve to be regarded as a Christian thinker and transformer of non-Christian thought.

\section{BIBLIOGRAPHY}

Alfeyev, Hilarion. St. Symeon the New Theologian and Orthodox Tradition. Oxford University Press, 2000.

A thanasius. The Life of Antony and the Letter to M arcellinus. Translated by R. C. Gregg. M ahwah: Paulist Press, 1980.

A rthur, Rosemary A. Pseudo-Dionysius as Polemicist: The D evelopment and Purpose of the Angelic Hierarchy in Sixth Century Syria. A ldershot: A shgate, 2008.

Damascius. The Philosophical History. Translated by P. A thanassiadi. A thens: A pamea Cultural A ssociation, 1999.

Dillon, J ohn. The Middle P latonists: 80 BC-AD 220. Ithaca: Cornell University Press, 1996.

Florovsky, Georges. The Byzantine Ascetic and Spiritual Fathers. Translated by R. Miller, A.-M . Döllinger-Labriolle and H. W. Schmiedel. Vaduz: Büchervertriebsanstalt, 1987.

Gersh, Stephen. F rom Iamblichus to E riugena. Leiden: B rill, 1978.

Gregory of Nyssa. The Life of Moses. Translated by A. J. Malherbe and E. Ferguson. New York: Paulist Press, 1978.

Hill, J onathan. The History of Christian Thought. D owners Grove: InterVarsity, 2003.

Homer. The Iliad. Translated by R. Fitzgerald. N ew Y ork: Farrar, 2004.

$\mathrm{K}$ harlamov, $\mathrm{V}$ ladimir. The $B$ eauty of the $\mathrm{U}$ nity and the $\mathrm{H}$ armony of the Whole: The Concept of Theosis in the Theology of Pseudo-Dionysius the Areopagite. Eugene: Wipf, 2009.

L outh, A ndrew. D enys the Areopagite. London: Continuum, 1989.

M oreschini, Claudio, and Enrico Norelli. Early Christian Greek and Latin Literature: A Literary H istory. 2 vols. Translated by M. J. O'Connell. Peabody: Hendrickson, 2005.

O'M eara, Dominic J., ed. Neoplatonism and Christian Thought. Norfolk: International Society for Neoplatonic Studies, 1982.

Perl, Eric D. Theophany: The Neoplatonic Philosophy of Dionysius the Areopagite. State University of N ew York, 2007.

Plato. The Dialogues of Plato. Translated by B. Jowett. Chicago: Encyclopaedia B ritannica, 2007.

Plotinus. The Enneads. Translated by S. M acK enna. A bridged by J. Dillon. London: Penguin, 1991.

Proclus. On the Existence of Evils. Translated by J. Opsomer and C. Steel. Ithaca: Cornell U niversity Press, 2003.

Ps.-Dionysius. The Complete Works. Translated by C. Luibheid and P. Rorem. New York: Paulist Press, 1987.

Riordan, William K. Divine Light: The Theology of D enys the Areopagite. San Francisco: Ignatius, 2008. 
Rist, J ohn M . Eros and Psyche: Studies in Plato, Plotinus, and Origen. University of Toronto Press, 1964.

Rorem, Paul. Pseudo-Dionysius: A Commentary on the Texts and an Introduction to Their Influence. Oxford University Press, 1993.

Sabo, Theodore. 'The Proto-Hesychasts: Origins of M ysticism in the Eastern Church.' Ph.D. diss., North-West University, 2012.

Sheldon-Williams, I. P. "The Pseudo-Dionysius." In The Cambridge History of Later Greek and Early M edieval Philosophy, ed. A. H. Armstrong, 457-472. Cambridge University Press, 1967.

Smith, Andrew. Porphyry's Place in the Neoplatonic Tradition: A Study in Post-Plotinian Neoplatonism. The Hague: Nijhoff, 1974.

The Acts of the Council of Chalcedon. Translated by R. Price and M. Gaddis. 3 vols. Liverpool University Press, 2005.

The P hilokalia: The Complete Text Compiled by St. Nikodimos of the Holy M ountain and St. Makarios of Corinth. Translated by G. E. H. Palmer, Ph. Sherrard and K. Ware. 4 vols. London: Faber, 1979-95.

Uždavinys, Algis, ed. The Golden Chain: An Anthology of Pythagorean and Platonic Philosophy. Bloomington: World Wisdom, 2004.

Yeats, William B. The Celtic Twilight and a Selection of Early Poems. New York: New A merican Library, 1962. 